Acta vet. scand. $1974,15,111-119$.

From the Primate Laboratory of the Department of Obstetrics and Gynaecology, University of Uppsala, and the Department of Clinical Biochemistry and the Department of Obstetrics and Gynaecology, Royal Veterinary College, Stockholm, Sweden.

\title{
PERIPHERAL PLASMA LEVELS OF ESTRONE AND PROGESTERONE IN PREGNANT PIGS TREATED WITH DEXAMETHASONE*
}

\author{
By
}

W. T. K. Bosu, L.-E. Edquist and B. Gustafsson

BOSU, W. T. K., L.-E. EDQVIST and B. GUSTAFSSON: Peripheral plasma levels of estrone and progesterone in pregnant pigs treated with dexamethasone. Acta vet. scand. 1974, 15, 111-119. - Five pregnant pigs of the Swedish Landrace Breed were treated with dexamethasone i.m. injections during early and late pregnancy. The daily dose of dexamethasone was never more than $100 \mathrm{mg}$. There were no significant changes in the maternal plasma levels of estrone and progesterone during dexamethasone injections. The dexamethasone initiated neither abortion nor parturition.

plasma levels; estrone; progesterone; pregnant sows; dexamethasone; parturition.

The induction of premature parturition in ruminants following the administration of synthetic corticosteroids in late pregnancy is now well documented (e.g. Fylling 1970, Edqvist et al. 1972). In swine the plasma levels of corticosteroids are reported to increase prior to parturition (Killian et al. 1972, Molokwu \& Wagner 1973). However, the relationship between the plasma levels of corticosteroids and the spontaneous onset of parturition is not well defined. Administration of $100 \mathrm{mg}$ dexamethasone ${ }^{\star *}$

* This study was supported by the Swedish Council for Forestry and Agricultural Research and the Ford Foundation.

* The following abbreviations and trivial names are used: Dexamethasone: $9 \alpha$-fluoro-16 $\alpha$-methyl-11 $\beta, 17 \alpha, 21$-trihydroxy-1,4pregnadiene-3,20-dione

Estrone: 3-hydroxy-1,3,5(10)-estratriene-17-one

Progesterone: 4-pregnene-3,20-dione

s: Standard deviation 
for three days to pigs in late pregnancy slightly shortened the gestation length (North et al. 1973). The objectives of the present investigation were to study the effect of dexamethasone administration to pigs in early and late pregnancy, its influence on the course of pregnancy and the maternal peripheral plasma levels of estrone and progesterone.

\section{MATERIAL AND METHODS}

Two pregnant gilts (nos. 1 and 2) and three pregnant sows (nos. 3, 4 and 5) of the Swedish Landrace Breed with accurate breeding records were used in this study. The mean gestational period in this breed is $115 \pm 1.5$ (s) days (Johansson \& Rendel 1963). Dexamethasone (Opticortinol, Ciba) was administered i.m. to the pigs (Table 1). Two pregnant pigs (nos. 1 and 2) received i.m. injections of $30 \mathrm{mg}$ of dexamethasone daily for three days during early pregnancy. Pig no. 1 received a further $100 \mathrm{mg}$ of dexamethasone i.m. on days 101, 103 and 105 of pregnancy, while pig no. 2 received $100 \mathrm{mg}$ dexamethasone i.m. daily from day 99 through day 101 of pregnancy. Two other pregnant pigs (nos. 3 and 5) received $30 \mathrm{mg}$ dexamethasone i.m. on six consecutive days beginning at day 100 of pregnancy. Pig no 4 received $30 \mathrm{mg}$ dexamethasone i.m. daily for three consecutive days starting from day 102 through day 104 of pregnancy.

Throughout the experimental periods, blood samples were collected daily between 10.00 and 12.00 a.m. by puncture of the ear veins. In addition, blood samples were obtained daily until three days after parturition from all the sows during late preg-

Table 1. Dexamethasone administration in pregnant pigs.

\begin{tabular}{|c|c|c|c|c|}
\hline $\begin{array}{l}\text { Pig } \\
\text { no. }\end{array}$ & $\begin{array}{l}\text { Stage of pregnancy } \\
\text { when treated (days) }\end{array}$ & $\begin{array}{l}\text { Dose } \\
\text { mg/day }\end{array}$ & $\begin{array}{c}\text { Gestation } \\
\text { length } \\
\text { (days) }\end{array}$ & Result \\
\hline 1 & $49-51$ & 30 & - & 一 \\
\hline 2 & 48,50 and 52 & 30 & - & - \\
\hline 3 & $100-1.05$ & 30 & 122 & 2 piglets \\
\hline 4 & $102-1.04$ & 30 & 116 & 15 piglets, 4 dead \\
\hline 5 & $100-105$ & 30 & 125 & 4 piglets, 2 dead \\
\hline 1 & 101,103 and 105 & 100 & 112 & 9 piglets, 1 dead \\
\hline 2 & $99-101$ & 100 & 120 & $\begin{array}{l}\text { slaughtered on day } 120 \text { of } \\
\text { pregnancy, } 3 \text { dead piglets } \\
\text { and } 1 \text { mummified foetus. }\end{array}$ \\
\hline
\end{tabular}


nancy. The blood samples were collected in heparinized tubes, centrifuged, and the plasma removed and stored at $-20^{\circ} \mathrm{C}$ until assayed.

The lengths of the gestation periods and the number of piglets were recorded at parturition (Table 1 ).

The peripheral plasma levels of estrone were measured using a rapid radioimmunoassay procedure (Edqvist \& Johansson 1972). When the concentrations of estrone and estradiol-17 $\beta$ in plasma samples from pregnant pigs were measured after column separation on Sephadex LH-20, it was found that the estrone/ estradiol ratio was about $9 / 1$. Therefore all the estrogen values here reported have been measured as estrone using the rapid radioimmunoassay procedure.

Peripheral plasma levels of progesterone were determined by a rapid competitive protein-binding technique (Johansson 1969). All steroid measurements were performed in duplicates.

\section{RESULTS}

The lengths of the gestation periods and the number of piglets recorded are shown in Table 1 . As can be seen, the injections of $30 \mathrm{mg}$ dexamethasone daily for three days to early pregnant pigs (48-52 days) did not result in abortion. Two pigs (nos. 1 and 4 ) were injected at about 100 days of pregnancy using a daily dose of 100 and $30 \mathrm{mg}$ of dexamethasone, respectively. Both these pigs farrowed normal litters after a gestation period of normal length, 112 and 116 days, respectively. The other three pigs (nos. 2, 3 and 5) had a longer gestation period than normal. Pigs nos. 3 and 5 received daily injections of $30 \mathrm{mg}$ dexamethasone for six days from day 100 of pregnancy and onwards. These two pigs farrowed after 122 and 125 days of pregnancy, respectively. Pig no. 2 received $100 \mathrm{mg}$ of dexamethasone on days 99,100 , and 101 of pregnancy. On about day 115 of gestation this pig showed symptoms of illness with fever and dullness. On day 120 of pregnancy, parturition started and three normally developed dead piglets were born. On the same day the general symptoms of illness became more severe and the pig was slaughtered. The uterus was examined and was found to contain one partly mummified foetus.

The results of the estrone and progesterone measurements in the two pigs (nos. 1 and 2) treated with dexamethasone during 
early pregnancy are presented in Fig. 1. No significant changes in the plasma levels of estrone and progesterone were seen following dexamethasone administration. The plasma levels of estrone and progesterone during late pregnancy in pigs treated with dexamethasone are shown in Figs. 2-6. Daily doses of 30

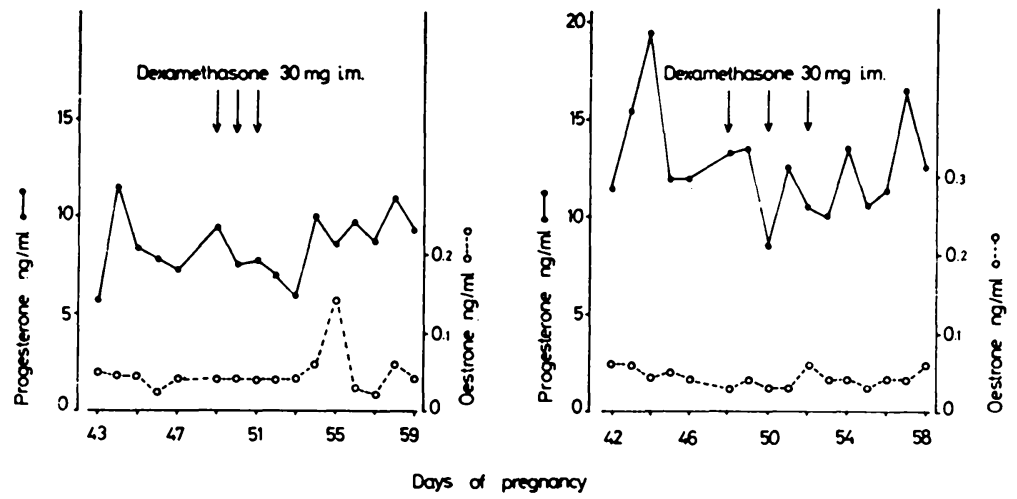

Figure 1. Plasma levels of estrone and progesterone in pigs no. 1 (left) and no. 2 (right) before, during and after dexamethasone administration in early pregnancy.

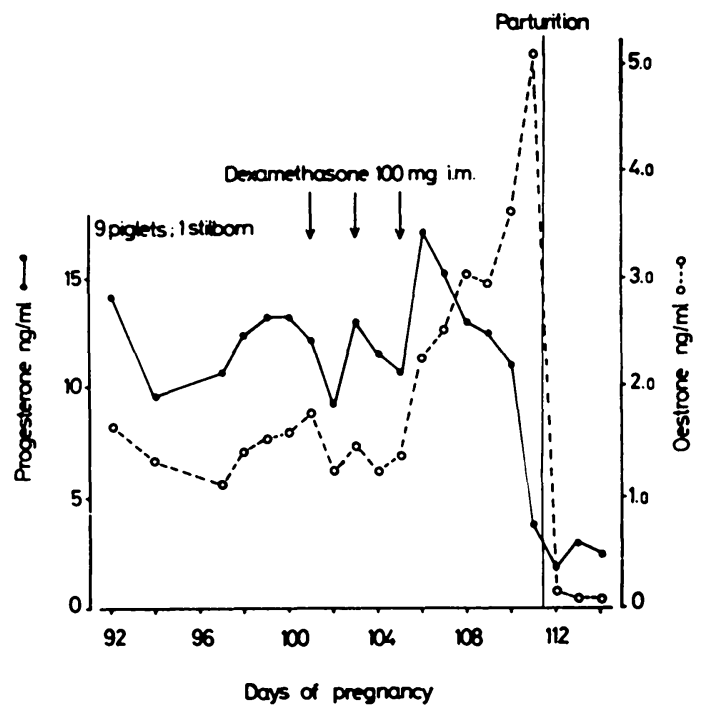

F ig u r e 2. Plasma levels of estrone and progesterone in pig no. 3 injected with $30 \mathrm{mg}$ dexamethasone daily for six consecutive days starting on day 100 of pregnancy. Also shown are the concentrations of estrone and progesterone in plasma until day 3 following parturition. 


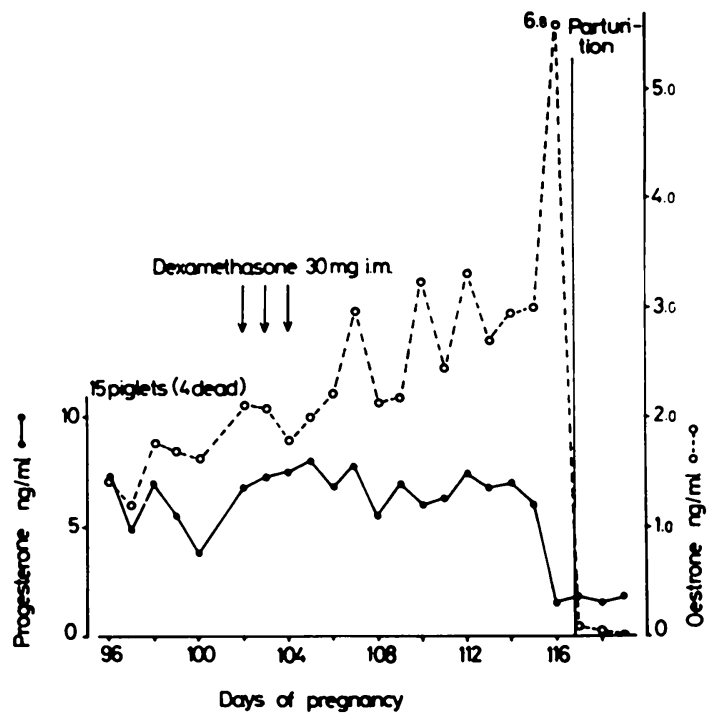

F i g u re 3. Plasma levels of estrone and progesterone in pig no. 4 from day 96 of pregnancy until day 3 following parturition. Dexamethasone $30 \mathrm{mg}$ was injected for three consecutive days starting on day 102 of pregnancy.

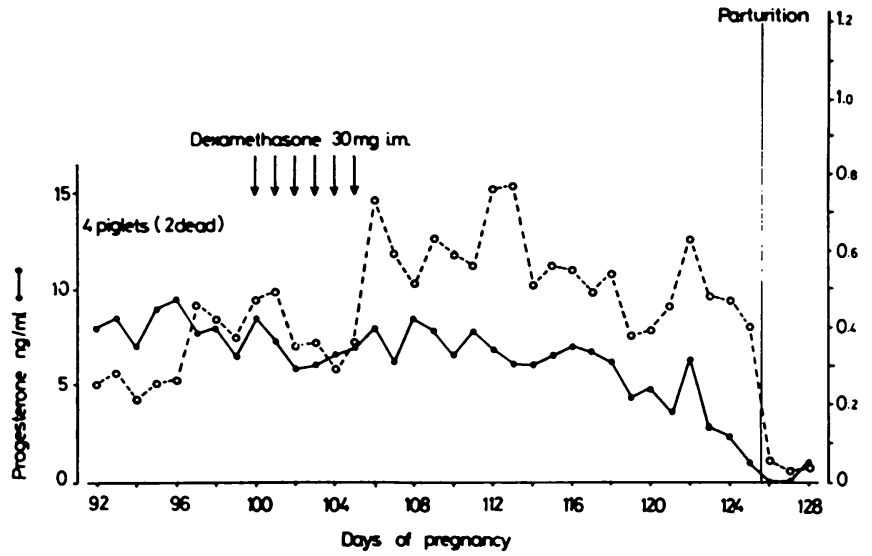

Figure 4. Plasma levels of estrone and progesterone in pig no. 5 from day 92 of pregnancy until day 3 following parturition. Dexamethasone $100 \mathrm{mg}$ was injected for six consecutive days starting on day 100 of pregnancy. 
mg of dexamethasone for three to six consecutive days during late pregnancy had no effect on the plasma levels of estrone and progesterone (Figs. 2-4). Figs. 5 and 6 show the peripheral plasma levels of estrone and progesterone in two pregnant pigs before, during, and after three treatments with $100 \mathrm{mg}$ dexamethasone daily. No significant changes in the steroid levels in the plasma were apparent during treatment. Increases in the plasma levels of estrone were observed prior to parturition in four of the pregnant pigs (Figs. 2-5). 'The highest concentrations of estrone occurred on the morning of the day of parturition in two cases (Figs. 3 and 5 ). The levels of estrone decreased dramatically after normal parturitions in four of the pigs investigated.

The peripheral plasma levels of progesterone in the pregnant pigs showed decreases in most cases during the last week of gestation. In all pigs farrowing normally, the plasma progesterone levels fell abruptly to comparatively low values about 24 hrs. before parturition (Figs. 2-5). In pig no. 2 which was slaughtered after several days of illness on day 120 of pregnancy, the estrone and progesterone levels showed continuous decreases during the last two weeks before slaughter (Fig. 6).

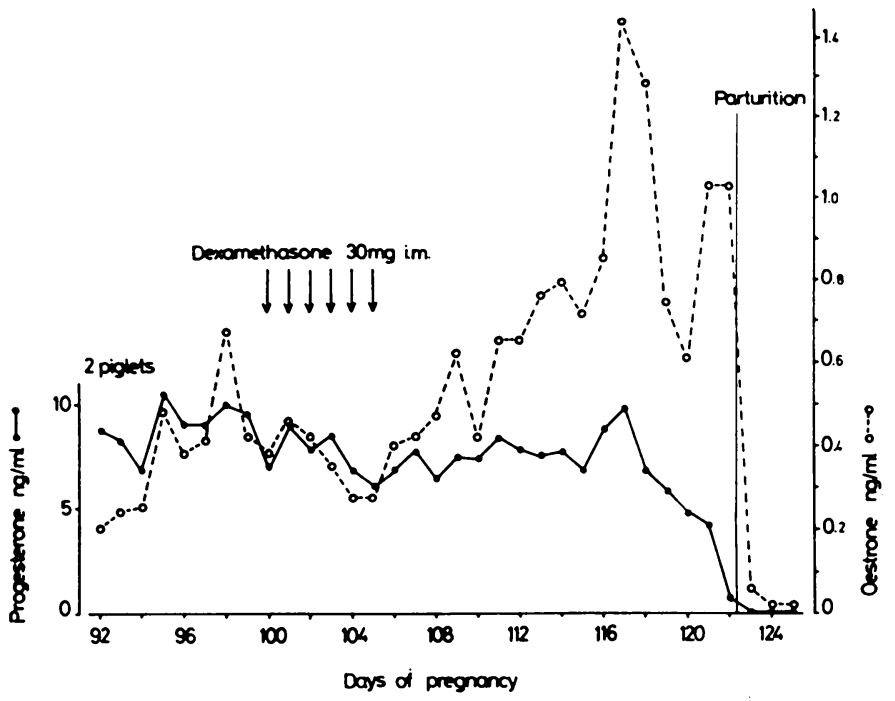

Figure 5. Plasma levels of estrone and progesterone in pig no. 1 during the second dexamethasone treatment in late pregnancy. 


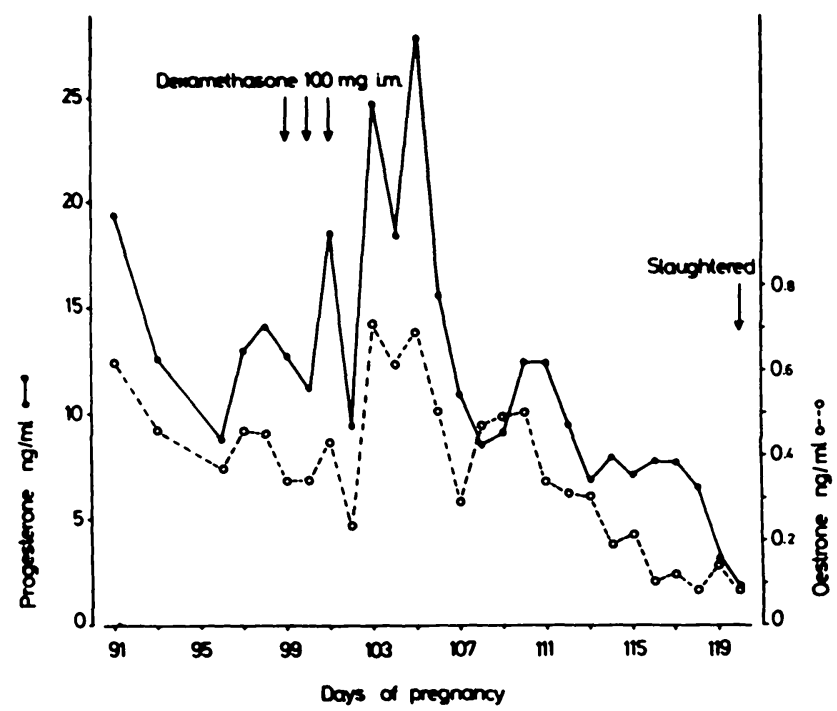

Figure 6. Plasma levels of estrone and progesterone in pig no. 2 from day 91 until day 120 of pregnancy. Dexamethasone $100 \mathrm{mg}$ i.m. was injected for three consecutive days starting on day 99 of pregnancy. The pig was slaughtered on the day of farrowing.

\section{DISCUSSION}

The gestation periods in the present study were in three cases longer than the normal for the breed used. However, in these three cases none of the pigs carried more than four piglets. It is well known that sows carrying only a few foetuses usually have longer gestation periods. The two pigs carrying litters of normal size farrowed after a normal gestation length. It can be concluded that dexamethasone injections in pigs carrying a few foetuses did not reduce the length of gestation. Neither could any significant reduction in the length of gestation in sows carrying litters of normal size be seen. Contrary to the present results it has been observed in a recent report that dexamethasone treatment in pigs in late pregnancy shortened the gestation periods when these were compared to normal untreated pregnant pigs (North et al. 1973). The present results indicate that dexamethasone injections in pregnant pigs in early or late pregnancy have no significant effects on the plasma concentrations of estrone and progesterone.

There appears to be a relationship between the number of live piglets and the maternal plasma levels of estrone. The highest 
concentrations of estrone $(5.0-6.8 \mathrm{ng} / \mathrm{ml})$ were observed in the sows with the largest number of piglets (Figs. 3 and 5 ). The estrone levels in the three pigs carrying only two to four piglets were generally less than $1 \mathrm{ng} / \mathrm{ml}$ of plasma.

Molokwu \& Wagner (1973) found estrone to be the principal estrogen during late porcine pregnancy. As previously mentioned, the estrone/estradiol ratio in plasma samples from pigs in late pregnancy in this study was $9 / 1$. The observation that progesterone levels in plasma decreased before parturition agrees with the reports of other workers (e.g. Ash et al. 1973, Edquist et al. in preparation), but differs from the results of a recent study in which the plasma levels of progesterone showed no consistent decreases until the day after parturition (Killian et al. 1972).

\section{REFERENCES}

Ash, R. W., P. G. Banks, G. Bailes, S. Broad \& R. P. Heap: Plasma estrogen, progesterone and corticosteroid concentrations in the pregnant, parturient and lactating sow. J. Reprod. Fertil. 1973, $33,359-360$.

Edqvist, L.-E. \& E. D. B. Johansson: Radioimmunoassay of estrone and estradiol in human and bovine peripheral plasma. Acta endocr. (Kbh.) 1972, 71, 716-730.

Edqvist, L.-E., L. Ekman, B. Gustafsson, S.-O. Jacobsson, E. D. B. Johansson \& J.-O. Lindell: Peripheral plasma levels of estrone and progesterone in pregnant cows treated with dexamethasone. Acta endocr. (Kbh.) 1972, 71, 731-742.

Fylling, P.: Premature parturition following dexamethasone administration to pregnant ewes. Acta endocr. (Kbh.) 1970, 66, 289295.

Johansson, E. D. B.: Progesterone levels in peripheral plasma during the luteal phase of the normal menstrual cycle measured by a rapid competitive protein binding technique. Acta endocr. (Kbh.) 1969, 61, 607-617.

Johansson, I. \& J. Rendel: Ärftlighet och husdjursförädling. (Heredity and animal breeding). LT:s Förlag, Stockholm 1963.

Killian, D. B., H. A. Garverick \& B. N. Day: Peripheral plasma progesterone and corticoid levels at parturition in the sow. J. Animal Sci 1972, 35, 1119.

Molokwu, E. C. I. \& W. C. Wagner: Endocrine physiology of the puerperal sow. J. Animal Sci. 1973, 36, 1158-1163.

North, S. A., E. R. Hauser \& N. L. First: Induction of parturition in swine and rabbits with the corticosteroid dexamethasone. J. Animal Sci. 1973, 36, 1170-1173. 


\section{SAMMANFATTNING}

Blodplasmanivåer av östron och progesteron hos dräktiga grisar behandlade med dexametason.

Fem dräktiga grisar (Svensk Lantras) behandlades under tidig och sen dräktighet med intramuskulära injektioner av dexametason. Den dagliga dosen dexametason överskred aldrig $100 \mathrm{mg}$. Inga signifikanta förändringar av plasmanivåerna av östron och progesteron kunde ses i samband med behandlingarna. Dexametasonet initierade varken abort eller prematur förlossning.

(Received September 24, 1973).

Reprints may be requested from: W. T. K. Bosu, the Primate Laboratory, Box 565, S-751 22 Uppsala, Sweden. 